\title{
Effect of biologically upgraded cocoa pod husk meal on growth, serum and antioxidant properties of two rabbit breeds
}

\author{
O. A. Olugosi (i), T. Ogunribido, J. O. Agbede and A. O. Ayeni
}

\begin{abstract}
Background: The study evaluated the growth performance, haemabiochemical and antioxidant profile of two breeds of rabbits fed diets containing varying levels of Rhizopus stolonifer fermented cocoa pod husk meal (FCPHM). Cocoa pod husk meal was taken through solid-state fermentation for a period of 2 weeks using Rhizopus stolonifer as its starter culture. One hundred and eighty, 5-week-old unsexed weaned rabbits 90 New Zealand white (NZW) and 90 Chinchilla (CHL) were randomly allocated into three dietary treatments, Diets I, II and III (0\%, 12.5 and 25\%FCPHM, respectively), and were arranged in a $2 \times 3$ factorial design ( 2 breeds and 3 diets) of a randomized block design.

Results: The study showed that the breed effect and dietary treatment were significant $(p<0.01)$ for total weight gain and feed conversion ratio with NZW breed fed 12.5\% FCPHM having higher values than CHL breed. Serum total protein concentration was significantly $(p<0.05)$ influenced by the dietary treatment, while alanine aminotransferase, globulin and total protein concentrations were significantly $(p<0.01)$ affected by the breed effect. The interactive effect of breed and dietary treatment was only significant $(p<0.05)$ for serum albumin concentration. Malondialdehyde concentration was significantly influenced by both dietary treatments $(p<0.05)$ and breed $(p<0.001)$ factors.
\end{abstract}

Conclusion: It was observed that $\mathrm{CHL}$ rabbits were more predisposed to stress than the NZW rabbits as indicated by the lipid peroxidation values, and according to this present finding, 12.5\% FCPHM is recommended as active feed ingredient in rabbit diets.

Keywords: Rabbits, Fermented cocoa pod husk meal, Breed effect, Serum and antioxidant profile

\section{Background}

In the light of escalating global population, FAO (2012) reported that from year 2000 to 2020, the projected world requirement for protein would increase tremendously and this would necessitate the imperative to explore other aspects and species in livestock production to bridge the gap of protein intake from animal origin. Traditionally, ruminant and monogastric (poultry and swine) animals have been the main sources of meat, but studies have shown that farming of rabbits (Oryctolagus cuniculus) and other micro-livestock species (grasscutters and

\footnotetext{
*Correspondence: oladom54@yahoo.com

Division of Nutritional Biochemistry, Department of Animal Production and Health, The Federal University of Technology, Akure, Nigeria
}

snails) is emerging in many developing countries like Nigeria as potential sources of animal protein (Ozung et al. 2017). However, it is envisaged that access to quality feeds may be a limiting factor to meat production of rabbits. This has engendered the need to consider alternative feed resources such as agro by-products and agro-industrial wastes that are readily available and under-utilized (Ozung et al. 2017).

Cocoa (Theobroma cacao) pod husks are a promising agro by-product that fit the definition of an alternative feed resource to be used in rabbit diet formulations, the practice of which its inclusion at various levels in animal diets has been reported (Adeyeye et al. 2019a). Ozung et al. (2016) reported that cocoa pod husk meal has between 7.70 and $9.37 \%$ crude protein, $8.83-11.68 \%$ 
ether extract and $9.30-10.85 \%$ ash, and a recent study by Olugosi et al. (2019) revealed that the nutritional value of cocoa pod husk meal can be improved by taking cocoa pod husk meal through a two-week solid fermentation procedure using Rhizopus stolonifer as its starter culture, reporting $18.20-21.92 \%$ crude protein, 5.54-6.39\% ether extract, $9.03-9.23 \%$ ash and vast reduction from 1.32 to $0.30 \%$; 9.60 to $8.19 \%$ in the theobromine content and crude fibre content, respectively. Studies on growth performance and nutritional studies have been carried out with cocoa pod husks on poultry (Nortey et al. 2015) and small ruminants, but little has been done on the effect of microbially fermented (detheobrominated) cocoa pod husk on growth performance, serum and anti-oxidant studies of rabbits, hence the objectives of this study.

\section{Methods}

\section{Ethical approval and experimental site}

This study was carried out after all animal experimental protocols were approved by the Research and Ethics Committee of the Department of Animal Production and Health, The Federal University of Technology, Akure, Nigeria. The feeding trial was conducted from Feb to March in 2019 at the Rabbitary Unit of the Teaching and Research Farm of the Department of Animal Production and Health, The Federal University of Technology, Akure (FUTA), Ondo State, Nigeria. The average daily temperature-humidity index (THI) of the experimental pen was $29.9^{\circ} \mathrm{C} \pm 1.56$. The THI, an indicator of thermal comfort level for enclosed animals, was calculated as described by Jimoh et al. (2018) using the following formula: THI $=t-$ $[(0.31-0.31 \times \mathrm{RHt}-14.4)]$, where $\mathrm{RH}=$ relative humidity $/ 100$ and $t=$ ambient temperature.

\section{Cocoa pod husk collection and fermentation}

Freshly discarded cocoa pod husk was collected, cleaned, chopped, sun-dried to reduce the moisture content and finely milled to produce cocoa pod husk meal. Cocoa pod husk meal (CPHM) was then taken through solid-state fermentation where $100 \mathrm{~g}$ of urea was dissolved in $100 \mathrm{l}$ of water used to moisten $100 \mathrm{~kg}$ sterilized CPHM. One litre of the starter culture, Rhizopus stolonifer, was used to inoculate the urea-treated CPHM and kept in a tray incubating chamber covered with cellophane for 14 days after which it was sun-dried for 5 days to inactivate the microorganism and this was carried out according to the protocol of Olugosi et al. (2019). Fermented cocoa pod husk meal was analysed for proximate composition (AOAC 1995) and labelled as fermented cocoa pod husk meal (FCPHM).

\section{Experimental animals and diet}

One hundred and eighty, 5-week-old weaned rabbits comprising ninety New Zealand Whites and ninety Chinchilla breeds were purchased from a reputable rabbit farm in Ogun state, Nigeria. The experimental rabbits had an initial live weight ranging from 467.05 to $518.20 \mathrm{~g}$ for New Zealand Whites and Chinchilla breeds, respectively. The animals were fed commercial pelleted feed for a one-week adaptation period, and the rabbits were given prophylactic treatment against bacterial and viral infections using a broad spectrum antibiotic-oxytetracycline hydrochloride eq. $50 \mathrm{mg}$ (soluble powder-5\% $\mathrm{w} / \mathrm{w}$ ) at recommended dosage of one teaspoonful per 41 of chlorine-free water. The animals were thereafter screened against ecto- and endo-parasites via subcutaneous injection of Ivermectin (Kepromec) at the recommended level $(0.20 \mathrm{ml}$ per rabbit). Thereafter, they were randomly assigned to the three experimental diets. The diets were formulated to meet the NRC (1977) minimum requirement for the physiological stage of the rabbits. Biologically upgraded cocoa pod husk meal was added as an active feed ingredient at $0,12.5$ and $25 \%$ of $100 \mathrm{~kg}$ of diet and designated as Diets I (control), II and III, respectively. The chemical composition of the experimental diets is shown in Table 1.

\section{Experimental layout and feeding trial}

The experiment was arranged in a $2 \times 3$ factorial arrangement in randomized block design (RBD), with two different breeds of rabbits namely: New Zealand White and Chinchilla breeds and three levels of the inclusion of fermented cocoa pod husk meal (0, 12.5 and 25\%). Each treatment was replicated ten times with 3 rabbits per replicate. The animals were randomly assigned to the experimental diets after balancing for weights and feeding trial lasted for eight weeks (56 days). The weekly live weights of the animals and daily feed intake were recorded, while feed conversion ratio (FCR) was estimated as the ratio of the feed intake to the live weight gain.

\section{Haematological and serum analysis}

At the end of the eight-week feeding trial, feed was withdrawn from the rabbits for a 12-h period in order to considerably reduce the gut fill. Ten rabbits were randomly selected per treatment to determine the carcass and relative organ characteristics, haematological, serum parameters and antioxidant activities. The rabbits were slaughtered after stunning in compliance with the procedure of the World Rabbit Association. The rabbits were bled, and blood was allowed to flow into plain and ethylenediaminetetraacetic acid (EDTA) bottles. The blood in the plain bottle was centrifuged; thereafter, 
Table 1 Chemical composition of the experimental diets (\%)

\begin{tabular}{|c|c|c|c|}
\hline Ingredients & $\begin{array}{l}\text { Diet I } \\
0 \% \mathrm{CPH}\end{array}$ & $\begin{array}{l}\text { Diet II } \\
12.5 \% \mathrm{CPH}\end{array}$ & $\begin{array}{l}\text { Diet III } \\
25 \% \mathrm{CPH}\end{array}$ \\
\hline Maize & 18.40 & 21.10 & 19.40 \\
\hline GNC & 8.70 & 7.80 & 4.10 \\
\hline PKC & 25.50 & 10.80 & 7.40 \\
\hline SBM & 4.50 & 4.10 & 3.10 \\
\hline Wheat offal & 6.90 & 3.40 & 0.40 \\
\hline GNH & 34.20 & 38.50 & 38.50 \\
\hline $\mathrm{FCPH}$ & 0.00 & 12.50 & 25.00 \\
\hline Vegetable oil & 0.80 & 0.80 & 1.10 \\
\hline Lysine & 0.10 & 0.10 & 0.10 \\
\hline Methionine & 0.10 & 0.10 & 0.10 \\
\hline Limestone & 0.40 & 0.40 & 0.40 \\
\hline Premix & 0.20 & 0.20 & 0.20 \\
\hline Salt & 0.20 & 0.20 & 0.20 \\
\hline Total & 100.00 & 100.00 & 100.00 \\
\hline \multicolumn{4}{|l|}{ Calculated composition } \\
\hline Dry matter, DM (\%) & 90.15 & 89.87 & 89.29 \\
\hline Metabolisable energy, ME (Kcal/kg) & 2505.89 & 2506.44 & 2501.95 \\
\hline Crude protein, CP (\%) & 15.92 & 15.95 & 15.68 \\
\hline Crude fibre, CF (\%) & 15.64 & 15.05 & 15.04 \\
\hline Calcium, Ca (\%) & 0.94 & 0.93 & 0.82 \\
\hline Av. Phosphorus, P (\%) & 0.69 & 0.64 & 0.59 \\
\hline Lysine (\%) & 0.87 & 0.88 & 0.79 \\
\hline Methionine (\%) & 0.60 & 0.59 & 0.59 \\
\hline \multicolumn{4}{|l|}{ Analysed composition } \\
\hline Dry matter, DM (\%) & 88.30 & 88.90 & 87.86 \\
\hline Crude protein, CP (\%) & 16.38 & 16.47 & 16.01 \\
\hline Crude fibre, CF (\%) & 15.62 & 15.07 & 14.95 \\
\hline Ash (\%) & 4.51 & 7.33 & 7.18 \\
\hline Ether extract (\%) & 6.32 & 5.14 & 5.06 \\
\hline Nitrogen-free extracts (\%) & 45.47 & 44.89 & 44.66 \\
\hline
\end{tabular}

GNC groundnut cake, PKC palm kernel cake, SBM soybean meal, GNH groundnut haulms, FCPH fermented cocoa pod husk

its serum was separated and frozen at $-20{ }^{\circ} \mathrm{C}$ prior to analysis. The total protein, cholesterol, creatinine, urea, aspartate amino transamine (AST) EC 2.6.1.1.1, alanine transamine (ALT) EC 2.6.1.1.2 and bilirubin were determined with a Reflectron ${ }^{\mathrm{R}}$ Plus $8 \mathrm{C} 79$ (Roche Diagnostic, GobH Mannheim, Germany) using commercial kits. Also determined from the serum were oxidative activities, the serum glutathione peroxidase (GPx) was determined as described by Rotruck et al. (1973), while the catalase (CAT) activity was determined as described by Aebi (1974), and superoxide dimutase (SOD) activity was determined by using the method of Misra and Fridorich (1972) and the procedure adopted by Kolawole (2016). Malondialdehyde concentration was carried out based on the principle of Varshney and Kale (1990). The blood samples collected in EDTA bottle were used for erythrogram (packed cell volume, haemoglobin concentration, red blood cell, white blood cell, mean cell volume and mean corpuscular haemoglobin) determination using haematology analyser.

\section{Carcass traits and measurement of relative organ weights}

Each rabbit was hoisted on a stationary thread hanging downwards on each hind limb which were widely spread apart. The slaughtered rabbits were eviscerated by using a scalpel to cut across the medial line on the ventral side. The rabbits were then flayed such that the fur and skin were removed to expose the underlying muscles. Thereafter, the dressed and eviscerated weights were expressed as percentages of the individual live weights of each rabbits, while the organ (liver, heart, lungs, spleen, kidney and bile) weights were expressed in gram per kilograms of the live body weights.

\section{Statistical analysis}

All collected data were subjected to two-way ANOVA and means separated using DMRT of SPSS version 23.0 (SPSS Software products, Marketing Department, SPSS Inc Chicago, IL, USA) and by fitting into the mathematical model:

$$
Y_{i j k}=\mu+D_{i}+B_{j}+(D B)_{i j}+\varepsilon_{i j k}
$$

where $Y_{i j k}$ observed mean, $\mu$ general mean, $D_{i}$ effects of diets, $B_{j}$ effects of breeds, $(\mathrm{DB})_{i j}$ interaction effects of diets and breeds of rabbits, $\varepsilon_{i j k}$ experimental errors.

\section{Results \\ Performance indices of New Zealand White (NZW) and Chinchilla (CHL)}

Table 2 shows that the breed effect and dietary treatments were significant $(p<0.01)$ for total weight gain (TWG) and feed conversion ratio (FCR) at 1st-4th weeks of the feeding trial.The NZW had higher values than CHL, the highest TWG (433.48 g) was recorded in the group fed diet containing $12.5 \%$ fermented cocoa pod husk meal (FCPHM), while the group fed diet containing 25\% FCPHM had the least TWG (300.02 g). The highest total feed intake (TFI) (1660.90 g) was recorded in the group fed diet containing 25\% FCPHM, and the least value $(1399.64 \mathrm{~g})$ recorded in the group fed the control diet. However, the TFI and average daily feed intake (ADFI) increased significantly $(p<0.05)$ as the level of FCPHM increased in the diets. The FCR (3.57) of rabbits fed the control and diet containing 12.5\% FCPHM were similar $(p>0.001)$, but significantly $(p<0.001)$ better than the group fed 25\% FCPHM-based diet (5.5). The interactive effects of breed and dietary treatments reveal 
Table 2 Growth performance of New Zealand White and Chinchilla rabbits fed varied levels of FCPHM from 1st to 4th week

\begin{tabular}{|c|c|c|c|c|c|c|c|}
\hline & IBW (g/rabbit) & FBW (g/rabbit) & TWG (g/rabbit) & $\begin{array}{l}\text { ADWG (g/ } \\
\text { rabbit/day) }\end{array}$ & TFI (g/rabbit) & $\begin{array}{l}\text { ADFI (g/ } \\
\text { rabbit/day) }\end{array}$ & FCR \\
\hline \multicolumn{8}{|l|}{ Breed } \\
\hline NZW & $466.45^{b}$ & 888.91 & $422.46^{\mathrm{a}}$ & $15.09^{\mathrm{a}}$ & 1497.12 & 53.47 & $3.54^{\mathrm{a}}$ \\
\hline $\mathrm{CHL}$ & $518.27^{\mathrm{a}}$ & 872.75 & $354.48^{b}$ & $12.66^{\mathrm{b}}$ & 1573.91 & 56.21 & $4.44^{b}$ \\
\hline SEM & 34.10 & 44.01 & 27.77 & 0.992 & 71.73 & 2.56 & 0.41 \\
\hline$P$ value & 0.049 & 0.716 & 0.004 & 0.004 & 0.292 & 0.292 & 0.005 \\
\hline \multicolumn{8}{|c|}{ \%FCPHM levels } \\
\hline 0.0 & 488.15 & 880.87 & $392.72^{\mathrm{a}}$ & $14.03^{\mathrm{a}}$ & $1399.64^{b}$ & $49.987^{b}$ & $3.57^{\mathrm{a}}$ \\
\hline 12.5 & 500.74 & 934.22 & $433.48^{\mathrm{a}}$ & $15.48^{\mathrm{a}}$ & $1546.00^{\mathrm{ab}}$ & $55.21^{a b}$ & $3.57^{\mathrm{a}}$ \\
\hline 25.0 & 527.37 & 827.39 & $300.02^{b}$ & $10.72^{b}$ & $1660.90^{\mathrm{a}}$ & $59.32^{\mathrm{a}}$ & $5.54^{b}$ \\
\hline SEM & 41.15 & 53.11 & 33.51 & 1.20 & 86.55 & 3.09 & 0.50 \\
\hline$p$ value & 0.616 & 0.139 & 0.001 & 0.001 & 0.018 & 0.018 & 0.001 \\
\hline \multicolumn{8}{|c|}{ Breed $\times$ FCPHM levels (\%) } \\
\hline \multicolumn{8}{|l|}{ NZW } \\
\hline 0.0 & 472.75 & 837.93 & $365.18^{b}$ & $13.04^{b}$ & $1224.48^{c}$ & $43.73^{b}$ & 3.35 \\
\hline 12.5 & 456.67 & 1002.54 & $545.87^{\mathrm{a}}$ & $19.50^{\mathrm{a}}$ & $1596.69^{b}$ & $57.02^{\mathrm{a}}$ & 2.93 \\
\hline 25.0 & 482.31 & 826.26 & $343.95^{b}$ & $12.28^{b}$ & $1670.20^{\mathrm{a}}$ & $59.65^{a}$ & 4.86 \\
\hline \multicolumn{8}{|l|}{$\mathrm{CHL}$} \\
\hline 0.0 & 518.56 & 923.82 & $405.26^{\mathrm{a}}$ & $15.01^{\mathrm{a}}$ & $1574.81^{b}$ & $56.24^{\mathrm{a}}$ & 3.89 \\
\hline 12.5 & 517.00 & 865.90 & $348.90^{b}$ & $11.47^{\mathrm{b}}$ & $1495.32^{c}$ & $53.40^{\mathrm{b}}$ & 4.29 \\
\hline 25.0 & 519.43 & 828.51 & $309.08^{c}$ & $9.15^{c}$ & $1651.60^{\mathrm{a}}$ & $58.99^{\mathrm{a}}$ & 5.34 \\
\hline SEM & 17.05 & 22.00 & 13.88 & 0.50 & 35.86 & 1.28 & 0.21 \\
\hline$p$ value & 0.735 & 0.148 & 0.002 & 0.002 & 0.042 & 0.042 & 0.275 \\
\hline
\end{tabular}

IBW initial body weight, $F B W$ final body weight, $T W G$ total weight gain, $A D W G$ average daily weight gain, $T F I$ total feed intake, $A D F I$ average daily feed intake, $F C R$ feed conversion ratio, FCPHM fermented cocoa pod husk meal, NZW New Zealand White, CHL Chinchilla

$\mathrm{a}, \mathrm{b}, \mathrm{c}$ Means on the same column with different superscripts are significantly different $(p<0.05)$

that significant $(p<0.05)$ differences existed in the TWG, average daily weight gain (ADWG), TFI and ADFI.

Table 3 shows the growth performance of the two rabbit breeds fed the varied inclusion levels of FCPHM at the 5th-8th weeks of the feeding trial. Only the TFI and ADFI were significantly $(p<0.01)$ influenced by the breed factor with the Chinchilla rabbits consistently having higher values than the NZW rabbit. The dietary inclusion of FCPHM had significant $(p<0.001)$ influence on the final body weight (FBW), TWG, ADWG and the FCR of the rabbits. The rabbits on diet containing 12.5\% FCPHM had significantly $(p<0.001)$ better values of weight changes and FCR than the rabbits on the control and 25\% FCPHM diets. The interaction between the breed and treatment effects was not significant $(p>0.05)$ for all performance traits measured.

\section{Carcass characteristics and relative organ weights}

Table 4 shows that only the relative weight of the liver was significantly $(p<0.001)$ influenced by the breed effect with NZW (31.86 $\mathrm{g} / \mathrm{kg}$ body weight) having higher value than CHL (27.89 $\mathrm{g} / \mathrm{kg}$ body weight). However, the live weight (LWT), eviscerated weight (EWT), dressed weight (DWT) and the relative weight of the heart were significantly $(p<0.05)$ influenced by the dietary treatment with rabbits fed diet containing 12.5\% FCPHM consistently having the highest values. The result further shows that the interaction for breed and treatment effect was significant $(p<0.01)$ for LWT only.

\section{Haematological profile, serum biochemical and antioxidant profile of New Zealand White and Chinchilla rabbits fed varied levels of FCPHM diets}

Table 5 shows that haematological indices measured were not significantly $(p>0.05)$ influenced by both the breed effect and dietary treatment. Also, the interaction between breed and treatment effect was not significant $(p>0.05)$ for any of the blood indices measured. Table 6 shows that only the serum total protein concentration was significantly $(p<0.05)$ influenced by the dietary treatment, while the alanine aminotransferase (ALT), globulin (GLOB) and total protein concentrations were significantly $(p<0.01)$ affected by the breed effect. The result further shows that the interactive effect of breed and 
Table 3 Growth performance of New Zealand White and Chinchilla rabbits fed varied levels of FCPHM from 5 to 8th week

\begin{tabular}{|c|c|c|c|c|c|c|c|}
\hline & IBW (g/rabbit) & FBW (g/rabbit) & TWG (g/rabbit) & $\begin{array}{l}\text { ADWG (g/ } \\
\text { rabbit/day) }\end{array}$ & TFI (g/rabbit) & $\begin{array}{l}\mathrm{ADFI}(\mathrm{g} / \\
\mathrm{rabbit} / \mathrm{day})\end{array}$ & FCR \\
\hline \multicolumn{8}{|l|}{ Breed } \\
\hline NZW & 888.91 & 1356.67 & 467.76 & 16.71 & $2263.90^{b}$ & $80.85^{b}$ & 4.84 \\
\hline $\mathrm{CHL}$ & 872.75 & 1307.62 & 434.87 & 15.64 & $2368.67^{\mathrm{a}}$ & $84.60^{\mathrm{a}}$ & 5.45 \\
\hline SEM & 44.01 & 36.35 & 23.66 & 0.85 & 34.98 & 1.25 & 0.442 \\
\hline$p$ value & 0.716 & 0.343 & 0.216 & 0.216 & 0.005 & 0.005 & 0.145 \\
\hline \multicolumn{8}{|c|}{$\%$ FCPHM levels } \\
\hline 0.0 & 880.87 & $1346.22^{b}$ & $465.34^{b}$ & $16.62^{b}$ & 2264.42 & 80.872 & $4.87^{b}$ \\
\hline 12.5 & 934.22 & $1478.21^{\mathrm{a}}$ & $543.99^{\mathrm{a}}$ & $19.59^{\mathrm{a}}$ & 2322.96 & 82.963 & $4.23^{\mathrm{a}}$ \\
\hline 25.0 & 827.39 & $1172.00^{c}$ & $344.61^{c}$ & $12.31^{\mathrm{c}}$ & 2361.48 & 84.338 & $6.85^{c}$ \\
\hline SEM & 53.11 & 60.06 & 27.84 & 0.99 & 41.17 & 1.47 & 0.52 \\
\hline$p$ value & 0.139 & 0.001 & 0.001 & 0.001 & 0.076 & 0.076 & 0.001 \\
\hline \multicolumn{8}{|c|}{ Breed $\times$ FCPHM levels (\%) } \\
\hline \multicolumn{8}{|l|}{ NZW } \\
\hline 0.0 & 837.93 & 1335.28 & 497.35 & 17.76 & 2185.40 & 78.05 & 4.39 \\
\hline 12.5 & 1002.54 & 1551.74 & 549.20 & 19.61 & 2267.74 & 80.99 & 4.13 \\
\hline 25.0 & 826.26 & 1182.99 & 356.73 & 12.74 & 2338.55 & 83.52 & 6.56 \\
\hline \multicolumn{8}{|l|}{$\mathrm{CHL}$} \\
\hline 0.0 & 923.82 & 1357.16 & 433.33 & 15.48 & 2343.43 & 83.69 & 5.41 \\
\hline 12.5 & 865.90 & 1404.68 & 547.89 & 19.57 & 2378.18 & 84.94 & 4.34 \\
\hline 25.0 & 828.51 & 1161.01 & 332.50 & 11.88 & 2384.40 & 85.16 & 7.17 \\
\hline SEM & 22.00 & 61.55 & 28.54 & 1.02 & 42.19 & 1.51 & 0.57 \\
\hline$p$ value & 0.148 & 0.420 & 0.582 & 0.582 & 0.396 & 0.396 & 0.628 \\
\hline
\end{tabular}

IBW initial body weight, $F B W$ final body weight, $T W G$ total weight gain, $A D W G$ average daily weight gain, $T F I$ total feed intake, $A D F I$ average daily feed intake, $F C R$ feed conversion ratio, FCPHM fermented cocoa pod husk meal, NZW New Zealand White, CHL Chinchilla

$a, b, c$ Means on the same column with different superscripts are significantly different $(p<0.05)$

dietary treatment was only significantly $(p<0.05)$ influenced for serum albumin concentration. Table 7 shows the serum antioxidant profile of New Zealand Whites and Chinchilla rabbits fed diets containing varied levels of fermented cocoa pod husk meal. The result shows that only the malondialdehyde concentration (MDA) was significantly influenced by both dietary treatments $(p<0.05)$ and breed $(p<0.001)$ factors.

The highest value $(82.75 \mu \mathrm{mol} \mathrm{MDA} / \mathrm{mg}$ protein) for lipid peroxidase (LPO) was observed in the group fed 25\% FCPHM containing diet, while the lowest value (31.48 $\mu \mathrm{mol} \mathrm{MDA} / \mathrm{mg}$ protein) was observed in the group fed $12.5 \%$ FCPHM containing diet.

\section{Discussion}

\section{Performance characteristics of rabbit}

The two breeds of rabbit utilized their feeds identically with no statistical difference in the total weight gain at the close of the trial implying the acceptance of the FCPHM-based diets by the rabbits. It was also observed that beyond $12.5 \%$ inclusion of FCPHM in the diets, the final body weight (FBW), TWG and FCR declined implying that effective utilization of the FCPHM by the two breeds of rabbit can only be achieved at $12.5 \%$ inclusion level. This negates the reports of Ozung et al. (2017) who asserted that rabbits fed $12.5 \% \mathrm{CPH}$ meal-based diet had lower FBW, total feed intake (TFI), TWG and FCR. However, the current findings are supported by Adeyeye et al. (2019b) who reported non-negative effect of the growth parameters in rabbits fed rumen liquor fermented ash cocoa pod husk.

Total feed intake (TFI) was seen to be higher in CHL breed, but with lower TWG and FCR which suggests breed differences in the utilization of FCPHM-based diet at 8th week of the trial. The daily intake of the rabbits was however higher than the range reported by Isika et al. (2012) who reported the average daily feed intake (ADFI) to range between 60.46 and $70.46 \mathrm{~g} / \mathrm{rabbit} /$ day for rabbits fed diets in which groundnut cake was replaced with cocoa bean meal. Ozung et al. (2017) emphasized that differences in ADFI values could be attributed to differences in feed materials, environmental influences and concluded that cocoa pod husk meal should be fermented prior to its inclusion in rabbits' diets. At 5th-8th weeks, the NZW rabbit breeds consumed lesser than CHL breeds with a numerical improvement of 33 units in 


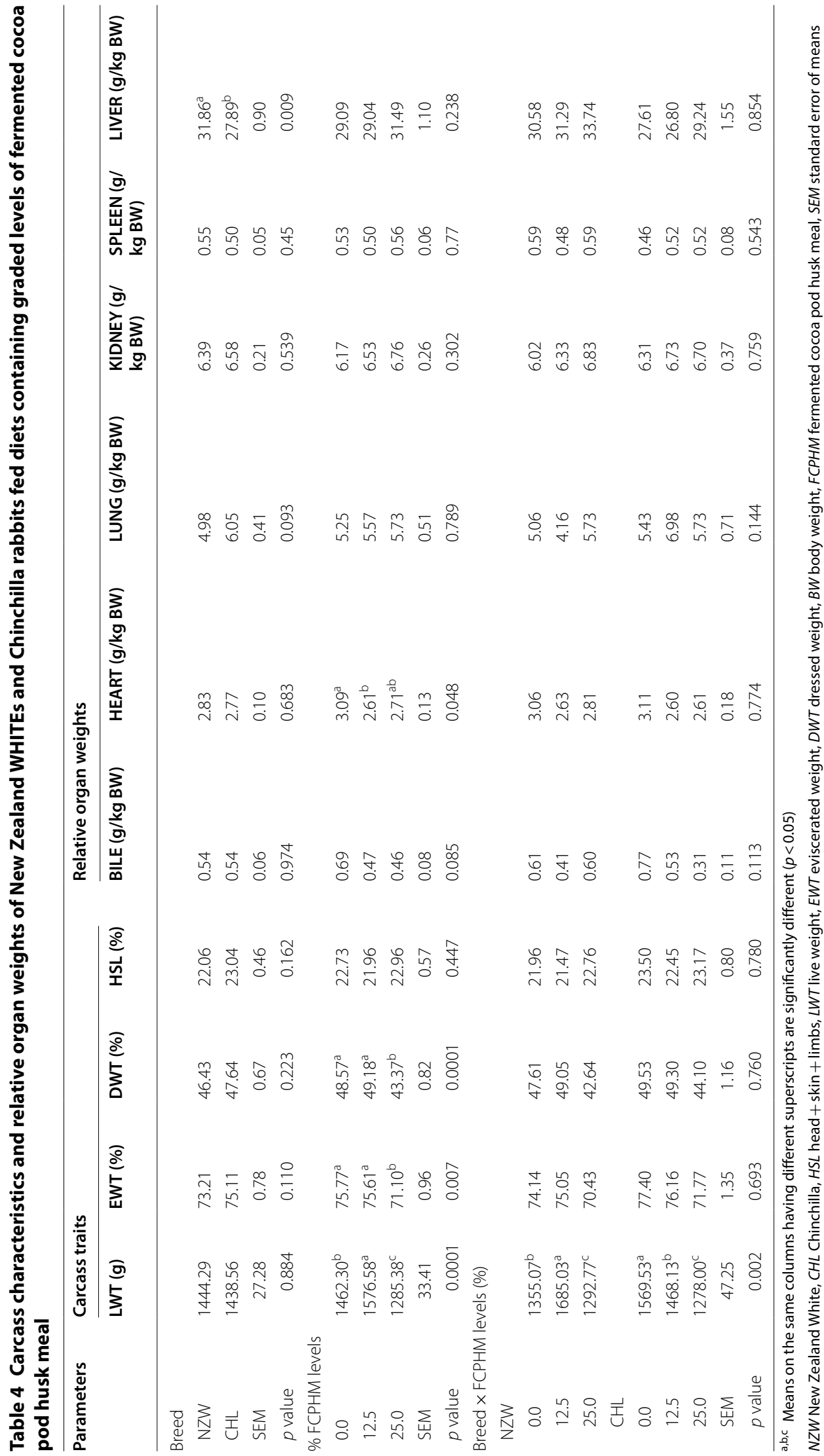




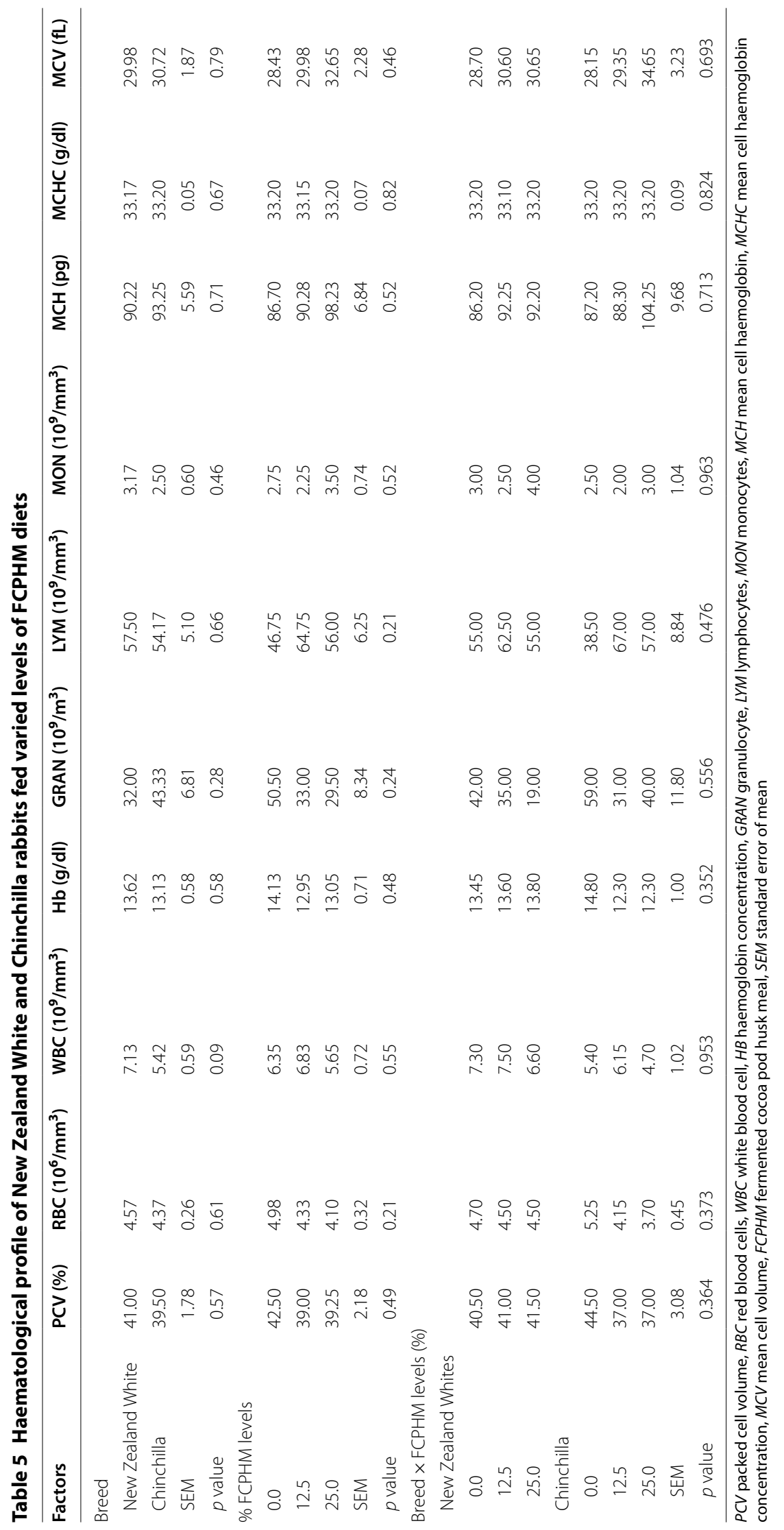




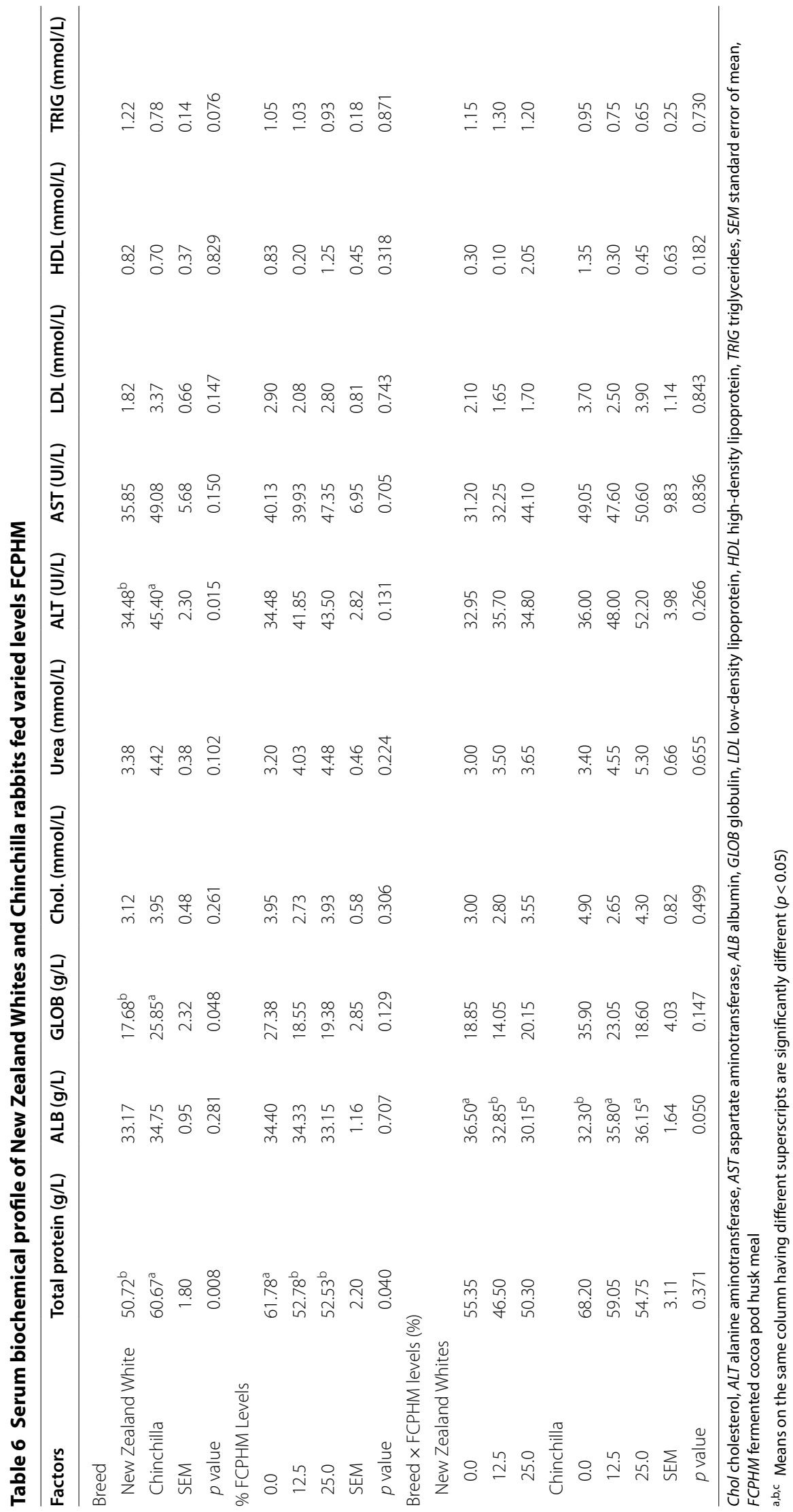


Table 7 Serum antioxidant profile of New Zealand White and Chinchilla rabbits fed diets containing varied levels of fermented cocoa pod husk meal

\begin{tabular}{|c|c|c|c|c|}
\hline Factors & SOD (\%) & $\begin{array}{l}\text { CAT } \\
\text { (mmol/ } \\
\mathrm{ml} / \mathrm{min})\end{array}$ & $\begin{array}{l}\text { LPO ( } \mu \mathrm{mol} \\
\text { MDA/mg } \\
\text { protein) }\end{array}$ & $\begin{array}{l}\text { GPx } \\
\text { ( } \mu \mathrm{mol} / \mathrm{ml} / \\
\text { min) }\end{array}$ \\
\hline \multicolumn{5}{|l|}{ Breed } \\
\hline $\begin{array}{l}\text { New Zealand } \\
\text { Whites }\end{array}$ & 30.33 & 1.13 & $38.21^{\mathrm{b}}$ & 0.07 \\
\hline Chinchilla & 43.42 & 1.40 & $69.23^{a}$ & 0.08 \\
\hline SEM & 4.24 & 0.18 & 11.33 & 0.01 \\
\hline$p$ value & 0.072 & 0.329 & 0.001 & 0.563 \\
\hline \multicolumn{5}{|l|}{ FCPHM levels (\%) } \\
\hline 0.0 & 39.38 & 1.42 & $46.93^{a b}$ & 0.08 \\
\hline 12.5 & 41.88 & 1.11 & $31.48^{b}$ & 0.08 \\
\hline 25.0 & 29.38 & 1.27 & $82.75^{\mathrm{a}}$ & 0.07 \\
\hline SEM & 5.19 & 0.22 & 13.88 & 0.01 \\
\hline$p$ value & 0.273 & 0.630 & 0.014 & 0.704 \\
\hline \multicolumn{5}{|c|}{ Breed × FCPHM levels (\%) } \\
\hline \multicolumn{5}{|c|}{ New Zealand White } \\
\hline 0.0 & 35.00 & 1.13 & 23.56 & 0.08 \\
\hline 12.5 & 39.25 & 1.15 & 35.59 & 0.08 \\
\hline 25.0 & 16.75 & 1.11 & 55.48 & 0.052 \\
\hline \multicolumn{5}{|l|}{ Chinchilla } \\
\hline 0.0 & 43.75 & 1.72 & 70.29 & 0.085 \\
\hline 12.5 & 44.50 & 1.06 & 27.38 & 0.07 \\
\hline 25.0 & 42.00 & 1.43 & 110.01 & 0.083 \\
\hline SEM & 7.34 & 0.32 & 19.63 & 0.02 \\
\hline$p$ value & 0.404 & 0.582 & 0.293 & 0.535 \\
\hline
\end{tabular}

$S O D$ superoxide dismutase, $C A T$ catalase, $L P O$ lipid peroxidation, GPx glutathione peroxidase, MDA malondialdehyde, FCPHM fermented cocoa pod husk meal

$a, b$ Means on the same column having different superscript are significantly different $(p<0.05)$

total weight gain (TWG). It was also observed that inclusion of the FCPHM beyond $12.5 \%$ led to a decline in the TWG and FCR of the rabbits, respectively. However, the interaction between the breed and dietary effect was not significant implying that they were independent of these factors.

\section{Carcass characteristics and relative organ weights}

The present study suggested that the live weights (grams), eviscerated weight (\%) and dressed weights (\%), except Head + skin + limbs (\%) (HSL) were influenced by the inclusion of FCPHM in the diets, but not significantly influenced by the breed effects. In line with the earlier report by Ozung et al. (2017), rabbits fed diet containing $12.5 \%$ FCPHM consistently had the highest live weight, eviscerated weight, dressed weight and HSL and beyond this inclusion level there was decline in values which further confirms the optimum inclusion level of FCPHM to be $12.5 \%$. The current results as regard the breed effect confirm the report of Nasr et al. (2017) that New Zealand crossbreeds dressed higher than Chinchilla crossbreeds.

Of the relative organ weights measured, only the relative weight of liver was significantly affected by the breed effect which is in consonance with Papadomichelakis et al. (2012), while only the relative weight of the heart was significantly affected by the levels of inclusion of FCPHM in the diets. These organs declined in values as level of FCPHM in the diet of rabbits increased beyond $12.5 \%$, further confirming this level as the safe level of inclusion that will not lead to atrophy of the heart and liver in the rabbits. However, the weights of all organs measured in this study fell within the normal range as reported by Nasr et al. (2017). Generally, the relative weights recorded in this study indicated that there was no visceral damage due to consumption of FCPHM and all internal systems were functionally normal. The weights of liver and kidney of the rabbit's showed that FCPHM did not have any metabolic disease or distress effect. Sani et al. (2017) reported that, if a feed contains anti-nutritional element, abnormalities in weights of liver and kidney would be observed. The abnormalities will arise due to increased metabolic rate of the organs in an attempt to reduce the toxic elements or to convert the anti-nutritional agents to non-toxic metabolites.

\section{Haematological indices}

According to Oloruntola et al. (2016), blood examination is an effective means of detecting the influence of nutrition physiological and pathological status of animals. In this study, it was observed that all haematological parameters measured were not statistically affected by the breeds and dietary treatments, but there was a numerical decrease in red blood cell (RBC) and granulocytes (GRAN) counts as the dietary inclusion levels of FCPHM increased. Although the values fell within the normal range earlier reported by Etim et al. (2014), these decreasing trends in RBC and GRAN could imply that the animals may become anaemic at higher levels of FCPHM inclusion and become more susceptible to infections. This current result agreed partly with the report of Adeyeye et al. (2019a) who indicated that all haematological parameters were not significantly influenced by processed cocoa pod husk, except for the haemoglobin ( $\mathrm{Hb}), \mathrm{RBC}$ and mean cell volume (MCV). The mean corpuscular haemoglobin concentration $(\mathrm{MCHC})$ values obtained in this study were not affected by dietary treatments and were within the normal range for healthy rabbits. The white blood cell differentials, namely lymphocytes, neutrophils, monocytes, basophils and eosinophils, stabilized within dietary treatments. The stability of these haematological indices has been adduced to nutritional adequacy and support of the diet's composition for 
normal haematopoiesis in the animals (Ogunsipe et al. 2017; Adeyeye et al. 2019a). Osaiyuwu et al. (2017) also reported that differences in the responses of some blood proteins (haemoglobin, albumin, transferrin and carbonic anhydrase) of New Zealand $\times$ Chinchilla crossbred rabbits could be underscored by genetic variability and hence biochemical polymorphism of crossbreed.

The haematological values obtained in this study though not significant were all numerically higher for the New Zealand White breed than in the Chinchilla breed except for haemoglobin concentration, lymphocytes, mean cell haemoglobin and mean cell volume that showed otherwise.

\section{Serum biochemical indices}

To assess the metabolic state of an animal, the serum metabolites levels are an important indicator to check (Neufingerl et al. 2013). In this study, only the total protein was significantly influenced by the dietary treatments of the entire metabolites examined. This negates the reports of Adeyeye et al. (2019a) which elaborated that the total protein, cholesterol, high-density lipoprotein (HDL) and low-density lipoprotein (LDL) were significantly influenced by the dietary inclusion of ashtreated cocoa pod husk meal in rabbit diets. They indicated that there were numerical increases in the values of the HDL and total protein up to $20 \%$ inclusion level of processed cocoa pod husk meal, but beyond which there were decline in values. On the other hand, the ALT, total protein and globulin concentrations in this study were significantly influenced by the breed effects. However, unlike haematological parameters, the serum metabolite values were numerically higher for Chinchilla than for the New Zealand Whites breed, except for HDL and triglycerides.

The albumin (ALB) and triglycerides (TRIG) were not significantly different, but fell within the normal range of values for rabbits as reported by Etim et al. (2014). Albumin and TRIG are important blood parameters that are indicative of nutritional status of an animal. The ALB levels indicate the level of protein in the blood, while the TRIG levels provide information on the overall nutrients metabolism (Meineri et al. 2017). The optimum ALB (34.33 g/l) and TRIG (1.03 mmol/l) concentrations obtained in this current study could therefore imply that the nutrient requirements of the rabbits were met in the diets provided. Although ALB concentration in serum is predicated on other factors that are independent of nutrition such as infections, trauma, hydration status, liver function and kidney disease (Sekine et al. 2013), the result of this study clearly shows that none of these extra-nutritional factors had considerable effects on the animals as indicated in the serum antioxidant status of the animals.

The AST and ALT did not show any significant differences across the dietary treatment and breed effects. These serum enzymes are largely functional in the liver and responsible for transamination in the metabolism of specific amino acids. Globulin (GLOB) concentrations, an important blood protein which when present in very low concentration could result in high rate of mortality (Adegbenro et al. 2016), were within the normal physiological range and significantly indifferent in this study.

\section{Serum antioxidative status}

The present study clearly revealed that all serum antioxidant indices, except lipid peroxidation (LPO), were not statistically different. The rabbits fed 25\% FCPHM containing diet had the highest serum MDA concentration, while the Chinchilla rabbits were more susceptible to oxidative stress than the New Zealand White rabbits. MDA is a lipid peroxidation index which is predictive of oxidative stress (Shehu et al. 2018). This implies that the higher MDA concentration values recorded for the rabbits fed diet containing 25\% FCPHM had greater free radicals-mediated cell damage and oxidative stress than the rabbits fed other diets. The statistically higher MDA concentration in the Chinchilla rabbit and diet containing 25\% FCPHM group could be adduced to genetic intolerance and the high dietary inclusion of FCPHM, respectively. It is noteworthy that the rabbits fed diet containing 12.5\% FCPHM had the lowest MDA concentration values and hence were least predisposed to free radicals-mediated cell damage and oxidative stress. The results obtained in this study for lipid peroxidation are supported by the reports of Meineri et al. (2017) and Shehu et al. (2018) who indicated that rabbits raised in cages were predisposed to oxidative stress than other group raised in pens due to psycho-emotional stress induced by immobilization in cages. The glutathione peroxidase (GPx), a seleno-enzyme that reduces phospholipid hydroperoxides by glutathione (GSH), was found to be similar across treatments and the values found to be within normal range of $0.05-0.15 \mu \mathrm{mmol} / \mathrm{mg} /$ protein reported by Reshma et al. (2015). Superoxide dismutase and catalase were not significantly influenced by the breed and dietary treatment.

\section{Conclusion}

From the foregoing, it can be concluded that Rhizopus stolonifer-FCPHM has great potential as alternative energy/protein feed resources where conventional energy and/or protein feed resources are grossly in short supply due to increase in import duties. Specifically, FCPHM can be used in the diets of growing NZW and CHL 


\section{rabbits at $12.5 \%$ inclusion level for best performance and overall health.}

\begin{abstract}
Abbreviations
ADFI: Average daily feed intake; ADWG: Average daily weight gain; ALB: Albumin; ANOVA: Analysis of variance; AOAC: Association of Official Analytical Chemist; AST: Alanine transamine; AST: Aspartate amino transamine; CAT: Catalase; CRD: Completely randomized design; CPHM: Cocoa pod husk meal; DMRT: Duncan's multiple range test; DWT: Dressed weight; EDTA: Ethylenediaminetetraacetic acid; EWT: Eviscerated weight; FBW: Final body weight; FCR: Feed conversion ratio; GLOB: Globulin; GPx: Glutathione peroxidase; GRAN: Granulocytes; Hb: Haemoglobin; HDL: High-density lipoprotein; HSL: Head + skin + limbs (\%); LDL: Low-density lipoprotein; LPO: Lipid peroxidase; LWT: Live weight; MCHC: Mean corpuscular haemoglobin concentration; MCV: Mean cell volume; MDA: Malondialdehyde concentration; NRC: National Research Council; RBC: Red blood cell; RH: Relative humidity; SOD: Superoxide dimutase; SPSS: Statistical package for the social sciences; T: Temperature; TFI: Total feed intake; THI:Temperature-humidity index; TRIG: Triglycerides; TWG: Total weight gain.
\end{abstract}

\section{Acknowledgements}

The authors are grateful for the financial support received from TETFund Abuja, year 2011/2012/2013 (Merged) Research grants intervention to carry out this study.

\section{Role of the Funder}

The funder provided financial aid to assist in carrying out the research work.

\section{Authors' contributions}

Conceptualization of the research work was done by AJO and OOA. Data curation carried out by OOA, OT, AAO and AJO. All authors managed all the activities of the experiment and interpreted the data collectively and gathered reference materials. Formal analysis and software design were carried out by OOA and OT and methodology of the experiment carried out by OOA, OT and AJO. Validation of the research work was approved by AJO. Investigation was carried out by OOA, OT and AAO. OOA prepared the first draft of the manuscript-original draft, while AJO reviewed and edited the manuscript and approved the final manuscript. All authors have read and approved the manuscript

\section{Funding}

This research work received financial support received from TETFund Abuja, year 2011/2012/2013 (Merged) Research grants intervention.

\section{Availability of data and materials}

The datasets used and analysed during the current study are available from the corresponding author on reasonable request.

\section{Ethics approval and consent to participate}

The experimental research complied with the institutional, national and international guidelines and was carried out after all animal experimental protocols were approved by the Research and Ethics Committee of the Department of Animal Production and Health, of the Federal University of Technology, Akure (FUTA), Nigeria. Committee's reference number is not available.

\section{Consent for publication}

Not applicable.

\section{Competing interests}

The authors declare that they have no competing interests.

Received: 25 October 2020 Accepted: 23 November 2020

Published online: 07 January 2021

\section{References}

Adegbenro M, Agbede JO, Onibi GE, Aletor VA (2016) Composite leaf meal: effects on haematology and biochemical indices of growing pigs. Arch Zootech 19(2):65-69

Adeyeye SA, Agbede JO, Aletor VA, Oloruntola OD (2019a) Processed cocoa (Thebroma cacao) pod husks in rabbits diet: effects on haematological and serum biochemical indices. Asian J Adv Agric Res 2(4):1-9

Adeyeye S, Ayodele S, Oloruntola OD, Agbede J (2019b) Processed cocoa pod husk dietary inclusion: effects on the performance, carcass, haematogram, biochemical indices, antioxidant enzyme and histology of the liver and kidney in broiler chicken. Bul Nat Res Centre 43:54

Aebi H (1974) Catalase estimation. In: Bergmeyer HV (ed) Methods of enzymatic analysis, vol 21. Verlag Chemic, New York, pp 673-684

AOAC (1995) Association of official analytical chemist. Official methods of analysis, 15th ed

Etim NN, Enyenihi GE, Akpabio U, Offiong EEA (2014) Effects of nutrition on haematology of rabbits: a review. Eur Sci J 10(3):413-424

FAO (2012) Food and Agriculture Organisation. Food outlook: global market analysis. Publication of the Food and Agriculture Organisation. Trade and Markets Division, Rome. http://www.fao.org/docrep/016/al993e/al993 e00.pdf. Accessed 23 May 2020

Isika MA, Nsa EE, Ozung PO (2012) Replacement value of processed cocoa bean meal for groundnut cake in rations for fryer rabbits. J Sustain Technol 3:118-127

Jimoh AA, Ayedun ES, Oyelade WA, Oloruntola OD, Daramola OT, Ayodele SO, Omoniyi IS (2018) Protective effect of soursop (Annona muricata linn.) juice on oxidative stress in heat stressed rabbits. J Anim Sci Technol 60(28)

Kolawole AK (2016) Effect of organic turmeric supplemented-diet in rabbits acutely exposed to ultraviolet radiation: oxidative stress in the blood. Anat Physiol 6:229

Meineri G, Giacobini M, Forneris G (2017) Evaluation of physiological parameters of the plasma oxidative status in rabbits. J Appl Anim Res 45(1):315-319

Misra HP, Fridovich I (1972) The univalent reduction of oxygen by flavins and quinines. J Biol Chem 247:188-192

Nasr MAF, Abd-Elhamid T, Hussein MA (2017) Growth performance, carcass characteristics, meat quality and muscle amino-acid profile of different rabbit breeds and their crosses. Meat Sci 134:150-157

National Research Council (1977) Nutrient requirements of rabbits. Subcommittee on rabbit nutrition, Committee on animal nutrition. Board on agriculture and renewable resources. 2nd, rev. National Academy of Sciences, Washington, DC

Neufingerl N, Zebregs YE, Schuring EAH, Traubwein EA (2013) Effects of cocoa and theobromine consumption on serum $\mathrm{HDL}$-cholesterol concentrations: a randomized controlled trial. Am J Clin Nutr 97:1201-1209

Nortey TN, Ewusi I, Kpogo LA, Oddoye EOK, Naazie A (2015) Cocoa pod husk with enzyme supplementation is a potential feed ingredient in broiler diets. Livest Res Rural Dev 27(5):87

Ogunsipe MH, Balogun KB, Oladepo AD, Ayoola MA, Arikewuyo MT (2017) Nutritive value of cocoa bean shell meal and its effect on growth and haematology of weanling rabbits. Niger J Food Agric Environ 13(1):23-28

Oloruntola OD, Ayodele SO, Agbede JO, Oloruntola DA, Ogunsipe MH, Omoniyi IS (2016) Effects of Alchornea cordifolia leaf meal and enzyme supplementation on growth, haematological, immunostimulatory and serum biochemical response of rabbits. Asian J Biol Life Sci 5(2):190-195

Olugosi OA, Agbede JO, Adebayo IA, Onibi GE, Ayeni OA (2019) Nutritional enhancement of cocoa pod husk meal through fermentation using Rhizopus stolonifer. Afr J Biotech 18(30):901-908

Osaiyuwu OH, Akinyemi MO, Akinlabi JO, Fatai RB (2017) Biochemical polymorphism in New Zealand White $\times$ Chinchilla Crosses. Niger J Anim Sci 19(2):16-22

Ozung PO, Kennedy Oko OO, Agiang EA (2016) Chemical composition of differently treated forms of cocoa pod husk meal (CPHM). Asian J Agric Sci 8(2):5-9

Ozung PO, Kennedy OO, Agiang EA, Eburu PO, Evans El, Ewas CE (2017) Growth performance and apparent nutrient digestibility coefficients of weaned rabbits fed diets containing different forms of cocoa pod husk meal. Agric Food Sci Res 4(1):8-19

Papadomichelakis G, Zoidis E, Fegeros K (2012) Dietarily induced changes in liver composition and weight of fattening rabbits. Livest Sci 144:190-196 
Reshma DR, Laura JM, Anne C, Chun-Mei Z, Duan C, Patrik R (2015) PYY dependent restoration of impaired insulin and glucagon secretion in type 2 diabetes following roux-en-y gastric bypass surgery. Cell Rep 15(5):944-950

Rotruck JT, Pope AL, Ganther HE, Hafeman DG, Hoekstra WG (1973) Selenium: biochemical role as a component of glutathione peroxidase. Science 179:588-590

Sani HM, Aljameel KM, Muhammad N, Maina BM, Abdulkarim A (2017) Performance and carcass characteristics of rabbit fed graded levels of Cassia tora seed meal. J Agric Ecol Res Int 13(1):1-5

Sekine S, Terada S, Aoyama T (2013) Medium chain triacylglycerol suppresses the decrease of plasma albumin level through the insulin-Akt-mTOR pathway in the livers of malnourished rats. J Nutr Sci Vitaminol 59(2):123-128

Shehu BM, Buba W, Mahmoud MM (2018) Serum malondialdehyde concentration of weaned rabbits raised in two different management systems. Niger J Anim Prod 45(2):67-70

Varshney R, Kale RK (1990) Effects of calmodulin antagonist on radiation induced lipid peroxidation in microsomes. Int J Radiat Biol 58:733-774

\section{Publisher's Note}

Springer Nature remains neutral with regard to jurisdictional claims in published maps and institutional affiliations.

\section{Submit your manuscript to a SpringerOpen ${ }^{\circ}$ journal and benefit from:}

- Convenient online submission

- Rigorous peer review

- Open access: articles freely available online

- High visibility within the field

- Retaining the copyright to your article

Submit your next manuscript at springeropen.com 